\title{
Meningkatkan Pemahaman Membaca Teks Narasi Pada Siswa SMP Advent Menggunakan Strategi Skimming
}

\author{
Aprilia Rosmarie, Mualimin \\ rose15494@yahoo.com,mualimin@lecturer.undip.ac.id \\ Universitas Diponegoro, Semarang \\ Developing Adventist JHS Students' Reading Cognition In Comprehending Narrative Story \\ Using Skimming Strategy
}

\begin{abstract}
To gather information, needs a good comprehensive in understanding the information. That's why the reading activity is important in our life. The researcher conducted a mixed method research and the aims were to investigate the significance improvement and students' responses after the researcher applied skimming strategy. The researcher analysed both in quantitative and qualitative method. The researcher investigated 7 th grader of Adventist School. The focus is about narrative text especially about legend stories such as Tangkuban Perahu, Rawa Pening, Borobudur Temple and Prambanan Temple stories. The researcher concluded and detected a significance improvement in reading skills performed by the students. Result showed that $p$-value $=0,0110433$. The students' score enhanced and it proved that students could comprehend the narrative text in their reading class.
\end{abstract}

Keywords: Reading Comprehension, Skimming, Narrative Text

Received date: 12 Mei $2020 \quad$ Revised date: 11 Januari $2021 \quad$ Accepted date: 19 Januari 2021

\section{INTRODUCTION}

Language is a bridge and as a communication tool to connect people with others. In this digital era, to get the information many language aspects appear in visual and auditory media and can not be separated with the written word. The English learners should master the four specific skills that belong to language competence such as listening and reading as the receptive skill, meanwhile speaking and writing as the production skill. Indonesia as the ESL or as the EFL country also concern about the education system especially in reading or literation activity. In Kurikulum 2013, the Education government prioritize the literation or reading activity in the curriculum. The main goal is the learners should understand the academic text extensively.

Mokodompit (2016) found out and uttered that the her students did not like to read. They felt embarrassed and were not too interested in reading activity. They underestimated and blocked themselves in reading class. And this problem not only found in Bandung area, but in all city in Indonesia. Then, Siahaan (2013) revealed that the problem in reading is a wide-spread problem in Indonesia as researcher found in her EFL class. Stoller (2015, p. 154) defined "Extensive reading as a way to deal with the instructing and learning of perusing in which students read huge amounts of understanding materials, all through the class, that are effectively perceived, fascinating, and charming".

Skimming strategy is finding out the topic and main ideas in each paragraph. Later, Novacek \& Burns (2014) mentioned that 'skim-reading' includes the way toward looking rapidly over data trying to cover progressively material while as yet being ready to hold a superficial perspective on the basic substance. Fatmawati (2014) investigated that skimming strategy is successful to maintain the students' boredom in reading as proved by Ataee et al (2015).

Utilizing skimming technique showed a positive reaction to the learners' to upgrade students' in reading activity (Santoso, 2017). Fauzi (2018) investigated that to help or boost up the speed of reading, the students could use skimming technique and it was succeed. Either comprehension or speed rates were demonstrated superbly by utilizing this technique. Not as in reading comprehensively in scholarly reason but moreover being able in personal purpose, such as read the daily paper, magazine, 
emails, letters, etc. It is demonstrated by Korsheed \& Rassoul (2018), they found that perusing comprehensively the daily paper utilizing skimming procedure could be a profitable instrument to improve pre-immediate learners' perusing comprehension skills.

Therefore, it is useful doing a research on the genuine circumstance within the Indonesia classroom, particularly in Semarang City. Considering the significance of being learned in reading, particularly moved forward in narrative story. And the researcher trusted that by doing this research, it can develop students' knowledge / skill in reading.

The researcher would like to carry out a study with the title "Developing Adventist JHS students' reading cognition in reading narrative story using Skimming strategy." Therefore the researcher intended to answer the following questions:

RQ1. Is there any significant improvement of students after being treated with Skimming strategy in reading narrative text?

The objectives are to examine the critical enhancement of students' comprehension in narrative text and what is their reactions after they are being instructed through skimming strategy. As the clarification over, it has taken the intrigued of numerous analysts in numerous nations in endeavor of giving the arrangement to the issues in reading skills. Through this consider, the researcher trusted that the result will be advantageous for the understudies to move forward their perusing aptitude. And can offer assistance the English instructors to execute this strategy to move forward students' perusing expertise through skimming, and provide a few thoughts for long-standing time analysts to conduct this technique in another class of content.

\section{LITERATURE REVIEW}

\section{a) Skimming Technique}

Varita (2017) suggested that EFL learners especially in senior high school level should develop their reading ability in daily life contexts to access knowledge. Ilter (2017) agreed that to pass in general education classroom, the students should have the ability in accessing complex content in the textbook. Guo (2012, p. 80) added that by having a good skill in reading, it may enforce the students to have positive attitudes and being more active in-class participation.

Skimming strategy is used to find out the topic and main ideas of each paragraph. It is agreed also by Novacek \& Burns (2014), 'skim-reading' includes the way toward looking rapidly over data trying to cover progressively material while as yet being ready to hold a superficial perspective on the basic substance. Fatmawati (2014) investigated that to accomplish students' reading comprehension, skimming strategy is really useful to maintain the students' boredom in reading.

Another researcher strengthen that using skimming strategy is successful to help the students' comprehension in reading (Ataee et al, 2015). Utilizing skimming strategy gave a positive respond to the learners' to enhance students' reading skill (Santoso, 2017). Skimming activity can be used in general purpose not only focus on academic purposes. Reading magazine, newspaper, advertisement, label product etc. Another benefit of using skimming strategy is proved by Korsheed \& Rassoul (2018), they found that reading comprehensively the newspaper using skimming strategy is a productive tool to enhance pre-immediate learners' reading comprehension skills.

\section{b) Previous and Related Research and Studies}

The researcher tried to jot down some previous and related research and studies about using skimming strategy. Muawanah (2011) found the improvement of students' reading ability by applying skimming method. Another research was conducted by Stoeckel, Reagan \& Hann (2012) and Waring (2011) agreed that this strategy helped students to enrich new vocabulary knowledge and understand the words that they had learned before. Yamashita (2013) conducted this strategy and it was successful for 61 undergraduate students in Japan and found that they felt comfort and in low anxiety.

In Susanti' (2013) research, she found that this strategy can help students who have struggled in reading and improve their reading comprehension. Jeon \& Day (2015) agreed that this strategy was the most effective to use it even to adults. To boost their speed of reading, skimming strategy can be used, and it succeed in Fauzi' (2018) research. Either comprehension or speed rates were proved excellently by using this strategy. 


\section{Hypothesis}

The hypothesis were proposed as written below:

H0: Skimming strategy does not affect significantly in reading comprehension skill.

Ha: Skimming strategy gives any significant effect in reading comprehension skill.

\section{METHOD}

It is a mixed method research which is using comparative design as the research design. The reading test is to check students' understanding in reading. It will be delivered in pre-test and post-test. The reason is to reveal whether Skimming has critical distinction in upgrading students' reading comprehension capacity. The sample was thirty students at SMP Advent Semarang in the school year of 2019/2020. The class is divided into two groups, the experimental group who were treated by Skimming strategy and the control group who were treated in conventional method.

To conduct the study, the researcher collected the data by distributing the reading test as the research instruments. There are 25 multiple choice questions in the test. The test was made and adapted from the book, English in Focus for grade 7. The researcher prepared the lesson plan and different materials in every meeting. The materials were taken from the school text book. The pilot test was given to another sample from SMP Advent, Semarang.

As the treatment, the teacher applied Skimming to experimental group. The teacher assisted the assigned text (e.g. narrative) and elaborated the Skimming strategy at first. The steps in applying Skimming strategy such as: First, read the title or introduction part, then peruse every first sentences in paragraph, keep attention in any picture, charts, or graphics and finally comprehend the last paragraph.

\section{RESULT AND DISCUSSION}

The result showed that the students improved significantly and their score increased. It proved that this strategy, skimming strategy was successful in reading activity. Their pre and post test score were contrasting and it showed there was a significance difference. This school has their own criteria of minimum score or KKM, for those who got 86-100 as their score, it means the score is very good, then for those who got 65-85 it means that the score is good enough and for those who got 0-64 means that the score is below the average or failed. The researcher tried to explicate the score or the result of the experimental and control group as shown in these tables below:

Table 1. The Score of Pre-test and Post-test in Experimental Class

\begin{tabular}{ccc}
\hline Students & Pre Test & Post Test \\
\hline A & 70 & 95 \\
\hline B & 65 & 80 \\
\hline C & 53 & 79 \\
\hline D & 42 & 80 \\
\hline E & 56 & 85 \\
\hline F & 58 & 72 \\
\hline G & 42 & 88 \\
\hline H & 46 & 70 \\
\hline I & 47 & 89 \\
\hline J & 79 & 100 \\
\hline K & 51 & 80 \\
\hline L & 70 & 90 \\
\hline M & 50 & 78 \\
\hline $\mathrm{N}$ & 48 & 83 \\
\hline O & 61 & 90 \\
\hline & P value & 0,0110433 \\
\hline & &
\end{tabular}

According to the result above, the $\mathrm{p}$ value is 0,0110433 . If $\mathrm{p}$ Value (Sig.) $\leq \alpha(0.05)$ : $\mathrm{H} 0$ is rejected. Ha is not rejected. It means there is an effect of Skimming strategy to enhance students' reading skills. Meanwhile, the score in the control group was not satisfied as proposed in this table below: 
Table 2. The Score of Pre-test and Post-test in Control Group

\begin{tabular}{ccc}
\hline Students & Pre Test & Post Test \\
\hline A & 67 & 68 \\
\hline B & 52 & 50 \\
\hline C & 45 & 47 \\
\hline D & 70 & 80 \\
\hline E & 48 & 58 \\
\hline F & 45 & 50 \\
\hline G & 34 & 34 \\
\hline H & 46 & 46 \\
\hline I & 46 & 46 \\
\hline J & 54 & 50 \\
\hline K & 58 & 50 \\
\hline L & 73 & 61 \\
\hline M & 58 & 58 \\
\hline N & 60 & 63 \\
\hline O & 52 & 52 \\
\hline & P value & 0,826048987 \\
\hline
\end{tabular}

It means there is no any improvement performed by the students. Chin (2007) uttered that the conventional method could not help the students to think creatively and it gave a big impact to the learning process. The class seemed not interactive, even the teacher was in high spirit but the students were unmotivated in learning or vice versa. The Indonesian government aches for all English educators to develop the intuitive homeroom on account of the interest for English capability at schools. Shomoossi (2004:98) recorded in his investigation and articulated, "The intelligent homeroom is the aftereffect of common collaboration among educators and understudies, understudies and understudies, bunch conversation, and some other study hall support."

In truth, when the learners were instructed and treated with skimming method, they can increment their accomplishment in reading comprehension through this strategy. As result, most learners can evoke earlier information and discover particular data from the reading content. They became active in the learning process and their score was getting better than the pre-test.

The researcher interviewed some students about their feeling in using skimming strategy as written in this excerpts below:

\#Excerpt 1

Student A:

"I am so happy, I can read fast and understand the meaning without wasting my time in reading the story."

Another student replied,

\#Excerpt 2

Student B:

"I loved narrative story, it makes me imagine on something unreal that never happened in real life. Honestly, I have read the story earlier in Bahasa, it helped me understand the context."

Denning (2000) agreed and stated that narrative text is a story that related with human event and it could be a fiction story. Moreover, the researcher found out the importance of mother tongue in learning. The last student said that he already read the story before in Bahasa so it would helped her understanding the story. Kurniati and Izhar (2015) found that using mother tongue in teaching can help the students develop and understand the lesson. Another research was conducted by Suhardin et al (2017), they got a connection between students' language acquisition and students' self-efficacy in learning. It showed that the students' motivation itself could construct a good atmosphere in learning. Further, $\mathrm{Li}$ (2009) stated that learning motivation is a solid inside drive for language learning. 
Based on the observation and interview, the researcher concluded that the students' motivation and attitude influenced their learning. Learners' motivation and attitudes are belong to the language acquisition factor in formal learning. Motivation and attitude are link together. According to Rasool \& Winke (2019) article, they proved that students' attitude had a big role in trigger their motivation in learning English. Attitude is acknowledged as a significant idea to comprehend human conduct and is characterized as a psychological express includes beliefs and feelings as mentioned by Latchanna \& Dagnew (2009). If students has bad attitude in learning English, such as feeling lack in confidence, it may block their mind set in learning and acquiring the English. And also can minimize their motivation in learning.

Another benefit of using skimming strategy as uttered by this student, Student C, as written in this excerpt below:

\#Excerpt 3

Student C:

"Now, I can summarize the whole story in seconds and could understand the context also."

Block \& Israel (2005) proved and said that summarizing activity can be a powerful strategy in order to comprehend a text. And this kind of activity can be applied in skimming strategy. Summarizing activity worked when the students were required to share the ideas and draw out the conclusion about the text that they had read. Siska (2000) added that by giving summarizing or making any judgments can lead the students to have Higher-Cognitive Thinking. Further, Moore (2004) stated that critical thinking is needed especially in academic life and it should be taught in a disciplinary-specific way.

\section{CONCLUSION AND SUGGESTIONS}

Based on the findings above, the researchers tried to conclude:

1. There is a critical enhancement on students after being educated or treated with skimming strategy especially in reading narrative text.

2. The students' responses showed good response, they became more active and enthusiastic in the learning process. Then they felt more motivated in learning English as we know the motivation has important keys in the learning process. Motivation is an inside power deciding the bearing of the persuading act and energizing the appropriate behaviour as stated by Ergun \& Avci (2018).

3. Skimming strategy was succeed in minimizing the students' boredom in reading, especially in reading narrative text. Moreover, this strategy was useful and helpful for the students to think critically. Long (2003:230) added that being critical thinker is important, "on the off chance that the understudies are not presented to this expertise, they will be denied the occasions to contend in the worldwide network."

Next, the researcher may suggest some suggestions for the teacher and for the future researcher:

1. The teacher may use this strategy not only in narrative text but in other genre of text such as descriptive, expository, spoof, procedural text.

2. The future researcher may apply this strategy in different level, for example in elementary or in senior high school level or in upper level such as college level..

\section{ACKNOWLEDGEMENT}

In this paper, I would like to thank my students in Adventist JHS Semarang who were being as participants in my mini-research. Also, I would like to thank my advisor, Mr. Dr. Mualimin Dip. Tesl, M.Hum for supporting and conducting me to do this research.

\section{REFERENCES}

Ataee, E. Fatemi, M. A. \& Ashraf, H. (2015). The Effect of Short Message Service on Iranian Lower Intermediate EFL Learners' Reading Comprehension through Skimming and Guessing Strategies Awareness. Theory and Practice in Language Studies, 5(7), 1428-1437. Retrieved July 2015 from Academy Publication. 
Bamford, Julian and Richard R. Day. (2004). "Extensive Reading Activities for Teaching Language”. Cambridge Handbooks for Language Teachers. Cambridge, England.

Block, C. \& Israel, S. (2005). Reading First and Beyond: The Complete Guide for Teachers and Literaty Coaches. Thousand Oaks: CAi Crowin Press.

Chin, C. (2007). Teacher questioning in science classrooms: what approaches stiulate productive thinking? J Res Sci Teach, 44 (6), 815 - 843.

Denning, S. (2000). The Springboard: How Storytelling Ignites Action in Knowledge Era Organizations. Boston, London: Butterworth Heinemann.

Diestha. (2011). Problematika Pembelajaran Membaca dan Menulis di SMP Beserta Solusinya. [Online]. Available at http://radiesthamanuist.blogspot.co.id/2011/11/problematikapembelajaran-membaca-dan.html. [29 ${ }^{\text {th }}$ April 2019]

Ergun, E. \& Avci, U. (2018). Knowledge Sharing Self-Efficacy, Motivation and Sense of Community as Predictors of Knowledge Receiving and Giving Behaviours. Journal of Educational Technology \& Society, 21(3), 60 - 73.

Fatmawati, Y. (2014). The Impact of Using Skimming and Scanning Strategies of Descriptive Text Towards Students' Reading Comprehension at Grade Eight of SMPN 22 Bandar Lampung. The Second International Conference on Education and Language ( $2^{\text {nd }}$ ICEL). Indonesia. [Online] [17 $7^{\text {th }}$ April 2019]

Fauzi, I. (2018). The Effectiveness of Skimming and Scanning Strategies In Improving Comprehension and Reading Speed Rates for the Students of English Study Program. Register Journal, 11(1), 101-120. Retrieved $3^{\text {rd }}$ June 2018 from Register Journal.

Freahat, N. M. \& Al-Faoury, O. H. (2011). Reading Passages and Skills in Jordanian High School and University EFL Textbooks: A Comparative Analytical Study. Theory and Practice in Language Studies, 5(1), 16-27. Retrieved January 2015 from Academy Publication.

Guo, S-C. (2012). Investigating the effects of outside reading on reading tendency and English proficiency. Extensive Reading World Congress Proceedings, 1, 79-81.

Ilter, I. (2017). Improving the reading comprehension of primary-school students at frustration-level reading through the paraphrasing strategy training: A multiple-probe design study. International Electronic of Elementary Education, 10(1), 147 - 161 September 2017.

Jeon, E-Y., \& Day, R. R. (2015). The effectiveness of ER on reading proficiency: A meta-analysis. Reading in a Foreign Language, 28(2), 246-265.

Khorseed, R. \& Rassoul, J. (2018). The Role of Using English Newspapers in Enhancing Preintermediate Level Learners' Reading Comprehension Skills. Theory and Practice in Language Studies, 8(10), 1370-1375. Retrieved October 2018 from Academy Publication.

Kurnianti, L. \& Izhar. 2015. Bahasa Ibu Dalam Pembelajaran Anak di Sekolah. Jurnal Pesona, 1 (1), Januari 2015, $1-14$.

Laatchanna, G. \& Dagnew, A. (June 2009). Attitude of teachers towards the use of active learning methods. E-journal of All India Association for Educational Research, 21(1), http://www.ejournal.aiaer.net/vol21109/12.\%20Latchana\%20\&\%20Dagnew.pdf

Li, C. (2009). A Research on Second Language Acquisition and College English Teaching. English Language Teaching, 2(4), $57-60$.

Long, C. J. (2003). "Teaching Critical Thinking in Asian EFL Contexts: Theoretical Issues and Pratical Applications," Proceedings of the $8^{\text {th }}$ Conference on Pan-Pacific Association of Applied Lingusitics.

Mokodompit, P L. (2016). Comparative study between cooperative learning Numbered Heads Together (NHT) and Think-Pair-Share (TPS) strategies to enhance students' Reading comprehension 
ability (Comparative Study at SMP Advent II Bandung and SMP Negeri 1 Parongpong). Acuity, Journal of English Language Pedagogy, Literature and Culture, 1(2), 1-12.

Moore, T. (2004). The critical thinking debate: how general are general thinking skills? Higher Education Research and Development, 23 (1), 3 -18.

Muawanah, F. (2011). Improving Students' Reading Comprehension Ability of Recount Text through Scanning and Skimming Technique at The Second Grade of SMPN 1 Gedongtataan Pesawaran. Unpublished Thesis. Bandar Lampung: University of Lampung.

Novacek \& Burns. (2014). SKIMMR: facilitating knowledge discovery in life sciences by machineaided skim reading. PeerJ 2:e483; DOI 10.7717/peerj.483

Rasool, G. \& Winke, P. (2019). Undergraduate students' motivation to learn and attitudes towards English in multilingual Pakistan: A look at shifts in English as a world language. System, 8(2), $50-62$.

Santoso, G. S. (2017). “The Use of Skimming Technique to Improve Students' Reading Comprehension of Descriptive Text at Grade Eight of SMP Immanuel Bandar Lampung" (2017). Electronic Theses and Dissertations. 2403. http://digilib.unila.ac.id/27417/2/A\%20SCRIPT\%20WITHOUT\%20DISCUSSION\%20CHAP TER.pdf

Shaffer, D. E. (2012). In defense of extensive reading for language learning. Proceedings of the KAPEE 2012 International Conference, South Korea, 14.

Shomoossi, N. (2004). The effect of teacher's questioning behavior on EFL classroom interaction: A classroom research study. The Reading Matrix, 4, 96 - 104.

Siahaan, E. V. (2013). Factors That Affect Students' Interest in Learning English. Bandung: Adventist University of Indonesia.

Siska, D. (2000). Thinking with a future perspective. Gifted Education International, 15, 29-44.

Stoeckel, T., Reahan, N., \& Hann, F. (2012). Extensive reading quizzes and reading attitudes. TESOL Quarterly, 46, 187-198. DOI: 10.1002/tesq.10

Stoller, F. L. (2015). Viewing extensive reading from different vantage points. Reading in a Foreign Language, 27 (1), $152-159$.

Suhardin, Juliangkary, E. \& Aguasfianuddin. 2017. Pengaruh Penggunaan Bahasa Ibu Dalam Konteks Belajar Mengajar Matematika Terhadap Daya Serap dan Motivasi Belajar Siswa Kelas VIII SMP Negeri 1 Ropang Tahun Pelajaran 2016/2017. Jurnal Media Pendidikan Matematika (JMPM), 5 (1), 33 - 38.

Susanti, M. (2013). An Analysis of Students' Reading Comprehension Achievement by Using Scanning and Skimming Techniques for Introvert and Extrovert Students at SMPN 29 Bandar Lampung. Unpublished Thesis. Bandar Lampung: University of Lampung.

Varita, D. (2017). Improving Reading Comprehension Through Literature Circles. English Education Journal (EEJ), 8 (2), 234 - 244.

Waring, R. (2011). Extensive reading in English teaching, In H. Widodo,.\& A. Cirocki (Eds.) Innovation and Creativity in ELT Methodology (pp. 2 -13). New York: Nova Publishers.

Yamashita, J. (2013). Effects of extensive reading on reading attitudes in a foreign language. Reading in a Foreign Language, 25(2), 248-263. 